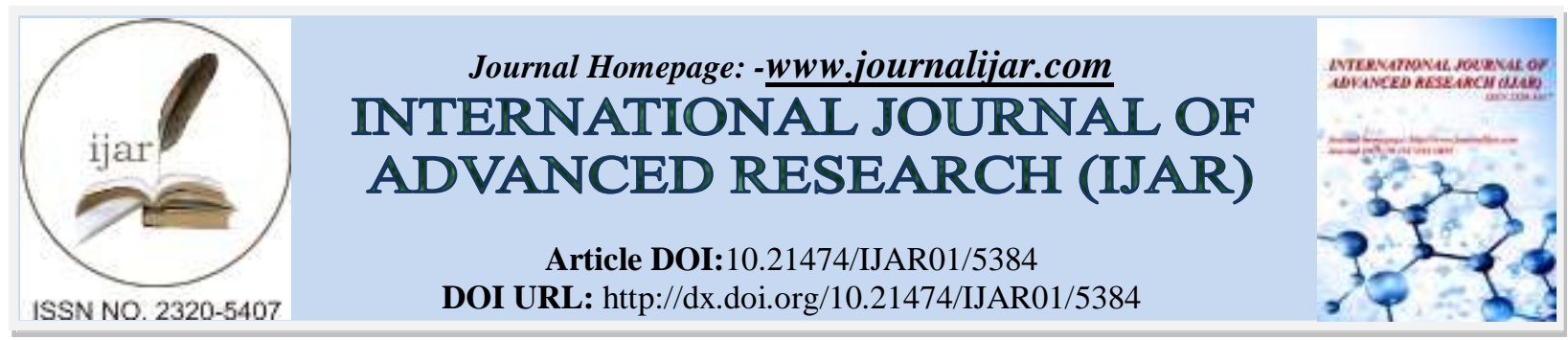

RESEARCH ARTICLE

\title{
CHANGING STATUS OF GIRL STUDENTS IN RELATION TO MARRIAGE AND FAMILY ASPECTS IN SOME RURAL AREAS OF ALMORA DISTRICT IN UTTARAKHAND, INDIA.
}

\author{
Shibani Nandi. \\ Researcher, GBPNIHESD Campus, Kosi-Katarmal, Almora- 263 643, Uttarakhand.
}

\section{Manuscript Info}

Manuscript History

Received: 10 July 2017

Final Accepted: 12 August 2017

Published: September 2017

\begin{abstract}
The status of women and girls is relatively low in India's male dominated society. Women constitute nearly half of the country's population with over $65 \%$ of them living in rural areas; they do play a vital role in the rural economy and, therefore, must be considered equal partners in the development process. A qualitative reform among the women is possible only through their education which would not only help in improving the overall educational status but also their overall economic development and independence. Therefore, one of the important aspects to be considered for women's education is to ensure proper schooling of girl children as they are the future of the country, and will form the future women force.

In view of comparatively low literacy rate of women $(70.7 \%$, men88.3\%; Census of India 2011) in Uttarakhand, it was pertinent to undertake an investigation on rural girl children (6-18 years) of Almora district to assess the attitudinal change towards their marriage (early or late) and family (type and size), in relation to their education. Further, mother's attitude towards dowry in daughter's marriage was also obtained. The study revealed that overall mindset of young girls and their parents towards early marriage has changed over the years and greater proportions are in favour of late marriage. The confident girls wished marrying after 25 years, following attainment of economical independence. The mothers too expressed their willingness to educate their daughters to higher level and not early marriage. On discussing dowry, a mixed opinion emerged amongst parents; while some favoured dowry as gift to their daughters for establishment of a new family, others preferred making their daughters economically independent by higher education. The type of family also appeared to have an influence on respondents' education, as more number of school going respondents belonged to a nuclear family.
\end{abstract}

Copy Right, IJAR, 2017,. All rights reserved.

\section{Introduction:-}

Education being one of the crucial indicators of status is vital to human development. Being male dominated the status of women and girl is relatively low in the Indian society. The low status of women is the result of social evaluation of their biological characteristics. At present worldwide population of women is equal to men (http://en.wikipedia.org/wiki/World_population- Wikipedia, the free encyclopedia; retrieved on 29th April, 2014) 
thus no subsequent development can be achieved if women, who form a big percentage of human resource, are not fully utilized. In India women constitute $48.5 \%$ of the population with over $65 \%$ of them living in rural areas (Census of India, 2011); they do play a vital role in the rural economy and, therefore, must be considered equal partners in the development process. Education is known to play important role in their empowerment. It has been suggested that a qualitative reform among the women is possible through their education and training together with appropriate apparatus being provided to them (Tewari, 1987). Several researchers have highlighted the importance of women's education (Kapadia, 1966; Kammeyer and Ginn, 1988; Jejeebhoy, 1995; Sen, 1997; Srivastava, 2005). These workers suggested that education raises the women's status by enhancing their capabilities, economic independence and also their ability to rely on themselves; it also brings them out of the confines of the domestic sphere and put them into contact with the outside modern world. They concluded that investment in women's education brings individual psychic and social benefits including increased productivity and also better chances for more educated women's children.

In addition to above, the status and role of women are closely linked with the pattern of marriage, particularly age at effective marriage. Early marriage of females is reflected on literacy rate, which gets lower (Pande, 1988). In India, customary early marriage of females has been prevalent in the early periods but has decreased with time. It is common among the socially backwards and uneducated communities, and in many rural communities illegal child marriage is still going on. Furthermore, the marriage of immature girls with aged men or widowers were not uncommon at earlier periods, including in the hill region of Uttarakhand (Pande, 1988; Chandola, 1999). Because there is pressure on woman to prove their fertility by conceiving as soon as possible after marriage, adolescent marriage is synonymous with adolescent childbearing (Anonymous, 2005).

The data pertaining to Uttarakhand state prior to its formation in 2000 is limited and fragmentary. Child marriage was reported prevalent in hills of Uttarakhand in early days particularly to support agriculture which was the main source of income (Chandola, 1999). The early data indicate that in rural Kumaun 54.6\% of the illiterate females entered into effective marriage life at 16 years and less, as compared to $54.7 \%$ with some level of education. On the other hand nearly $55 \%$ of illiterate females consummated their marriage at the age above 16 years against about $45 \%$ with some education (Saxena, 1975).

Prior to formation of Uttarakhand, the mean age of females at the time of marriage in the hill areas was reported to be different from that in the Bhabar and Tarai belts. In the hills, the mean age was 15.53 years. However in the case of Paharis settled in Tarai region, the mean age was reported to be 17.19, for the Boksas 14.31 years, and for Muslim with no educational background 15.27 years (1971 data; Tripathi, 1980). A noticeably fast change in the mean age at marriage in Kumaun region was reported between the years 1961, 1971 and 1986. It was reported that women married by the age of 15 years were $54.7 \%$ in $1961,37.7 \%$ in 1971 and $15.8 \%$ in 1986 . Similarly, in Almora district the values were $58.61 \%$ in 1961, 37.93\% in 1971 and further reduced to $16.5 \%$ in 1986 (Srivastava, 1979). Thus in a particular region, and between rural and urban areas there would be expected variation in the mean age at marriage. It must be mentioned that mean age at marriage of girls in India has gone up over the years and there is wide variation in each state.

Illiterate (uneducated) women face more hardships in life compared to literate ones; they have high levels of fertility as well as mortality, and suffer from malnutrition and various health related problems. Further when a girl or women is illiterate, not only she suffers in life but the entire family has to bear the consequences. Thus, a woman who does not know the importance of education in life does not emphasize the same for their kids (Kaur, 2013).

It is known that life in rural mountain areas is difficult and living conditions tougher (Nandi \& Joshi, 2015). Basic requisite of a moderate living, such as potable water, fuel wood, fodder, hospital and maternity centres, veterinary services, schools, postal services, roads and vehicular transport, marketing and banking centres are not easily available in many mountainous places. The far flung habitations remains largely secluded, villages small sized, and scattered far and wide. It is further exacerbated by the outmigration of the males resulting in deprivation of the skills, education and entrepreneurship of the men. The women folk are thus forced to perform the functions of the active labour force; this includes all the farm activities as well as entire domestic work. The hard lives, low income and enormous responsibilities of hill women can however be improved through education, which can contribute to the changes in a society and thus should be seriously provided to children, both boys and girls (Nandi \& Joshi, 2015). Children, future of a country, are the future human resources on which a country's developmental process 
depends. Hence investigations on education level of girl children would be relevant as they will form the future women force.

\section{Objectives of the study:-}

In view of the above reasons and the low literacy rate of women in the state, it was thought necessary to undertake an investigation to assess the views of respondent girl students (6-18 years) focusing on the following: (a) age at marriage and decision on choice of groom, (b) views of parents on their daughter's marriage and dowry, and (c) type and size of family. These aspects have been analyzed in relation to educational level of the respondents.

\section{Study site and Methodology:-}

The study was conducted during September 2013 to May 2014 in Almora district, Uttarakhand (Figure 1) which comprises of 11 blocks (Bhasyia-chhana, Bhikyasen, Chaukhutiya, Dhaula Devi, Dwarahat, Hawalbagh, Lamgarah, Saalt, Syalde, Takula and Tarikhet) and the corresponding forest area. Based on the female literacy rate, the blocks were arranged into two categories, i.e. high and low (source: VikasBhawan, Almora, Govt. of Uttarakhand; based on Census of India, 2011). Since the female literacy rate in rural areas of Almora district is $67.88 \%$, blocks with literacy rate up to $67.88 \%$ were categorized under 'low level' whereas the blocks with literacy rate of above $67.88 \%$ were placed under 'high level' of literacy. Thus from each of these categories, two blocks each- with lowest and highest literacy rates, comprising a total four blocks, namely Dhaula Devi (60.67\% literacy rate; $35 \mathrm{~km}$ from Almora), Lamgarah (64.09\%; $33 \mathrm{~km}$ from Almora), Hawalbagh (73.69\%; $14 \mathrm{~km}$ from Almora), and Tarikhet (74.04\%; $56 \mathrm{~km}$ from Almora) were chosen (Figure 1). Information relating to geographical position, area, population and literacy rate of different sites in Almora district selected for the study is summarized in Table 1.

Once the blocks were selected, from each of these blocks 75 respondents were predominantly selected for interview thus, making a total sample of 300 respondents. The criteria for selection of respondents was only girl children aged between 6 to 18 years (excluding married, widow and divorce) with their parents (without any caste, race or creed) in order to get a complete range of information. The sample is thus representative of various variables like age, standard or class, drop-out, family, financial condition, parental education, and parental attitude of the respondents. The sample consisted of school going and drop-out students of various types of school (Government, Private and Under schemes).

\section{Results and Discussion:-}

A comparison of data from different areas of the country clearly demonstrates the fact that there is a close relationship between education and the level of economic development. Education is therefore, regarded as one of the most important ingredients of economic development. Education inter alia improves both quality skill of population. Investment in education is considered investment in development of human resources (Joshi, 1988). Moreover, education is widely perceived as a key factor in improving the status of women and even more importantly, as an agent for developing modern attitude and rational outlook. Lack of education among women hinders their ability to bring about economic development and social transformation of the community and of the nation as a whole (Srivastava, 2005).

In the present study the levels of education of the respondents have been classified in to four categories- (a) Below $5^{\text {th: }}$ : Those who study below $5^{\text {th }}$ class, (b) Below $10^{\text {th }}$ : Those who study between $6^{\text {th }}$ to $10^{\text {th }}$ class, (c) Below $12^{\text {th: }}$ : Those who study between $11^{\text {th }}$ to $12^{\text {th }}$ class, and (d) Drop-out: Those who have left the school after enrolment.

Based on the class category, out of the total 300 respondents chosen, $58(19.33 \%)$ were girls below $5^{\text {th }}$ class, 102 $(34.00 \%)$ have education level below $10^{\text {th }}$ class, $126(42.00 \%)$ were below $12^{\text {th }}$ class, and the remaining $14(4.67 \%)$ were drop-out students (Table 2).

\section{Education and related factors:-}

Respondent's Age:-

All the respondents (300 nos.) were initially grouped into different age categories, and their education levels ascertained. The age structure of the respondents indicate that $18.67 \%$ were in age group of $6-10$ years, $33.67 \%$ in 11-15 years and $47.66 \%$ of them between $16-18$ years (Table 2).

Age has always remained an important factor influencing the education of an individual. In our country, mostly in rural areas, early child marriage (after 14 years) is still continuing, and this affects the level of education. Data on 
the respondents' education under different age categories are provided in Table 2. The younger generation have better opportunities and being more conscious of the value of education, are usually more careful than those belonging to the older generation. In this study it was noticed that in case of drop-out students only $3.57 \%$ (due to some illness) belong to 6-10 yrs group, 6.93\% (help provided to mother in domestic work and care of siblings) fall in 11-15 yrs group and $3.50 \%$ (due to domestic work, distance of school, and waiting for good marriage proposal) in 16-18 yrs group. The percentage of drop-out students was maximum (6.93\%) in the age group of 11-15 yrs (Table 2). Thus, in general the percentage of drop-out students is very less.

\section{Age of girl's marriage:-}

Respondent's attitude and age at marriage:-

Data representing respondents' education and attitude towards age at marriage is depicted in Figure 2. It is very interesting that among the respondents who favoured marriage below 18 years, $66.67 \%$ were drop-out, $8.33 \%$ below $12^{\text {th }}$ class and $25.00 \%$ below class 10 , while none were present under the category of class 5 students. Among the respondents who favoured marrying between 18 to 24 years, $13.33 \%$ were students of class $5,26.67 \%$ students of class $10,20.00 \%$ students of class 12 , and majority $40.00 \%$ were drop-out students. On the other hand, respondents who preferred marriage at 25 years and above, $44.69 \%$ (maximum) were students of class $12,34.80 \%$ students of class 10 , and $20.51 \%$ were students of class 5 ; however, none of drop-out students favoured marriage at the age of 25 years and above (Figure 2).

There is a positive relationship between the education of respondents and the preferred age of marriage, i.e. higher the education level, higher is the preferred age at marriage. This is clearly evident in the case of respondents of class 10and 12; on the other hand in case of drop-out they were generally interested to get married at an early age. Education, thus, has a significant influence in postponing the age at marriage. Thus it is evident from the forgoing analysis that the attitude of the rural children towards the early marriage has changed and a greater proportion of them were in favour of late marriage. In general, the respondents preferred to get married only after first settling down, preferably after 25 years.

Mother's attitude towards daughter's age of marriage:-

It is important to examine the attitude of parents (mostly mothers) towards their daughter's marriage. When the parents were asked about their daughter's marriage and at what age they wanted to marry their daughters, interestingly majority of the parents, particularly mothers, expressed their willingness to educate their daughter up to higher level and were not in favour of early marriage. Most of them indicated that since they themselves were married at child hood below 15 years, they could not understand what life meant? They sadly said, "Before being adult we were married and subsequently our life was not ours, it became our in-laws. Over time things have changed and presently girls are becoming educated, and hence they have the right to enjoy their life freely. Life means not just marriage and bearing children. We are sufferers but we do not want our daughters to suffer and wish that first they get properly educated and then be independent as without financial independence nothing is possible". According to most mothers, girls should marry after 25 years. On the other hand, parents who were not in favour of higher education and thought to marry their daughters early were mostly parents of drop-out children.

Age at marriage is of particular interest because it generally marks the point at which certain options in education are foreclosed. Different studies have identified a number of factors that seems to influence marriage timing. Various studies have also shown that age at marriage rises with higher education (Driver, 1963; Krishnamurthy, 1968; Jha et al., 1969; Hussain, 1972; Raina, 1972). Increases in age at marriage are associated with major sociostructural changes such as increased educational attainment, urbanization, emergence of new roles for women and the number of children they bear (Rindfuss and St. John, 1983; Bloom and Trussell, 1984; United Nations, 1987, 1988; Oppenheimer, 1988; Jejeebhoy, 1995; Kaufman and Meekers, 1998). Jejeebhoy analyzed 51 studies based on a number of data sources, mostly the World Fertility Surveys, and Demographic and Health Surveys (DHS), and found that education is the single factor most strongly related to the postponement of marriage, but the relationship may be subject to threshold effects.

Marriages in younger age keep women subjugated. Amendment of the Child Marriage restraint Act in 1976 raised the minimum legal age for marriage from 15 to 18 for young women and from 18 to 21 for young men. However, in many rural communities illegal child marriages are still common. Because there is pressure on women to prove their fertility by conceiving as soon as possible after marriage, adolescent marriage is synonymous with adolescent childbearing (Anonymous, 2005). 


\section{Arrangement/Choice of marriage:-}

In the Indian society the arrangement/choice of marriage has always remained the responsibility of the parents and the brides generally have no voice in selecting their partner. Thus any objection on her part relating to marital arrangement is considered as a sign of her dissoluteness. In this context it is necessary to see whether any changes have taken place in the attitude of the respondents towards their own marriage.

When the respondents were asked about their choice of marriage, then majority said that they wished to choose their partner, however some said that they wanted their parents to decide. When some mothers were asked about this, then they answered that days have changed unlike theirs and presently they would arrange their daughter's marriage with their opinion; without their consent the parents are not likely to arrange their marriage.

The interview schedule was conducted with only respondents (girl children) whose age was between 11 to 18 years because respondents in the age group of 6 to 10 years are small girls, and hence they would not understand much about this question. Thus among the total 244 respondents, $4(1.64 \%)$ were students of class $5,102(41.80 \%)$ that of class $10,126(51.64 \%)$ of class 12 and $12(4.92 \%)$ were drop-out who were between 11 to 18 years.

Among the respondents $57.38 \%$ said that their parents would arrange marriage after taking their consent while $42.62 \%$ said that they will totally agree to their parent's decision. It can be observed from Figure 3 that amongst the drop-out students $83.33 \%$ said they will agree with their parent's opinion, while $16.67 \%$ said that their parents would take their consent. Among class 12 students majority, i.e. $65.08 \%$ said that parents would take their consent while $34.92 \%$ would not. On the other hand nearly equal percentage of students of class 10 would agree or disagree with their parent's decision. On the other hand all (i.e. $100.00 \%$ ) of class 5 respondents said that their parents would want to marry them after taking consent from them (Figure 3).

Thus it can be observed that in recent times the girl students are maturing and developing confidence following education and thus they wish to have their say in selecting their life partner. Figure 4 depicts a recent Kumauni marriage ceremony where the girl is educated and employed, and around 25 years of age. A number of rituals are carried out by the bride and groom's relatives, dressed in traditional attire (Figure 5).

Mother's attitude towards dowry in daughter's marriage:-

When mothers were asked whether they would give dowry during their daughter's marriage, then majority said that at their marriage time dowry system was not so popular, but since now the system has started in many rural regions, they indicated if necessary, they would agree to dowry because they are concerned about their daughter's future and her social status in her in-law's house. They mentioned that some essential gifts like jewellery, furniture, clothes, utensils, etc must be given to the newly married couple for their future life. Therefore, they would prefer to give gifts during their daughter's marriage, of course within their limits, so that their daughters don't face the harassment and opposition of her in-laws. Some mothers opined that they are not in favour of show casing of valuables during dowry; instead they would prefer to educate their daughters so that they can be economically independent which will be the best gift from their side.

The dowry system among the people of middle class and even the lower middle class has assumed an awesome state. The bargaining on the amount of kind of dowry has not only dehumanized the status of woman but also demoralized the parents making an honest living. The system, rather a curse, is a new tradition in Kumaun and Garhwal regions of Uttarakhand, and was more prevalent in earlier days (Pande, 1988; Chandola, 1999). The girls used to lead a pitiable life and were unwanted, had secondary status at home and became un-honoured and suppressed slave in the house of her in-laws. Her condition was shocking, particularly when the husband was a 'migrant' (Pande, 1988). The cost of marriage is rising steeply in view of high prices of gold ornaments and the custom of giving gifts such as furniture and household effects to the brides. The girls are constrained to live under strain when income of the parents does not permit this scale of marriage expense. It has, however, diminished nowadays with growing education in Uttarakhand. Among very low income groups in rural areas of Uttarakhand, dowry system is still not that important (Pande, 1988; Chandola, 1999).

In India, dowry is still prevalent in several communities and in different region of the country. Srinivas (1983) observed that dowry is the product of the various socio-economic factors, like the monetization of economy, growth of education, hyper gamy, lesser female work participation, emulation of higher caste practices by lower caste, etc. He indicated that a change over to the system of dowry can be attributed to the increased wealth which enables 
people to spend more lavishly on weddings in their struggle for social recognition (Srinivas, 1983). Thus, dowry at present has gained a status symbol and people who do not practice it are sometimes devalued in the society (Majumdar, 2001). According to Roulet (1996) dowry is not merely an institution confined to valorisation of marriage but serves more importantly as a central institution to define social prestige and status thus becomes an important dimension of people's representation of themselves and other. Rajaraman (1983) agrees with the view that dowry and social prestige are closely associated. According to him it is this status and prestige, which encourages people to participate in its practice. Whilst the dowry system has been legally abolished, in practice its prominence is more marked than ever, and the payments have increased substantially. The custom has permeated all religions and social classes (Caldwell et al., 1983; Mandlebaum, 1999).

\section{Family:-}

The role and status of women in the family give her the position in the society. While education level of parents influences the educational quality of their children (Nandi \& Joshi, 2015), family conditions have a bearing on the privileges of children, including schooling. In this context we have to find out the autonomy enjoyed by today's girls in rural Almora in various aspects of family life. The following section analyze the type of respondent's families and fulfill their demand within the family.

Types:-

People in rural India generally are reluctant to undertake family planning. A young bride in a rural area is brought up to belief that her own wishes and interest are subordinate to those of her husband and his family. Due to the preference of giving birth to "sons", women have to forcefully give birth to children until a son is born because most Indian thinks that only sons can light their heritage towards the future. Therefore, for this reason they may have to produce more children, sometimes 4 or more. Thus, besides this reason widely prevalent among all communities irrespective of their caste, creed and religion, other factors like unawareness and illiteracy contribute to rapid growth of population. These not only affect the health of mother and pose financial pressure on the family, but also on the quality and/or level of education.

Keeping the above in mind, it is important to study the status of the girl children in different type and size of family in rural Almora.

The type of respondent's families also influences the education they attain. This has been analyzed in this investigation in relation to 'joint' or 'nuclear' family. The graph showing respondent's education and type of family is given in Figure 6. As far as type of family is concerned, it was clear that $39.00 \%$ of the respondents lived in joint family and $61.00 \%$ lived in nuclear family (Figure 6). This shows that nuclear family systems are popular in rural Almora. When analyzed on the basis of education level of the respondents it was found that $28.57 \%$ of drop-out children lived in joint families, while majority $71.43 \%$ lived in nuclear families. Among the class 12 students $42.06 \%$ of them lived in joint families while $57.94 \%$ lived in nuclear families. Thus, it can be noticed in general that the type of family seems to influence the respondents' education as more school going respondents lived in a nuclear family. However, presence of some drop-out cases in nuclear family can be attributed to requirement of girls for domestic work.

Size:-

The status of girl children in different size of family ( small $\leq 2$, or large $>2$ children in a family) in rural Almora is given in Figure 7. It was observed that among the total respondents $55.67 \%$ of them belong to small family while $44.33 \%$ belong to large family. When analyzed on the basis of level of education, among respondents of class 5 category, $82.76 \%$ belong to small family while only $17.24 \%$ fall under large family category. Amongst class 10 students, $54.90 \%$ belong to small family while $45.10 \%$ belong to large family; among class 12 students, the values are slightly different with $48.41 \%$ under small family category whereas $51.59 \%$ under large family. Interestingly for drop-out respondents, only $14.29 \%$ were from the small family while majority $85.71 \%$ belong to large family (Figure 7).

It can be observed that in general the size of the family plays an important role in influencing the number of respondents going to school. In recent years a gradual change is occurring in the minds of the parents who provide more care and opportunities to their children. Small family help in proper upbringing providing better quality of education; moreover a family bearing a large number of children adversely affects the health of the mother as well as that of the children. Further, satisfaction of the children's genuine physical and psychological needs, especially 
for parental love is more important for happiness of the children. But it is very difficult to provide proper care to the children in a large family. Hence, alternatively the idea of possessing a small family and enjoying happiness was realized by most of the respondents' parents.

\section{Conclusion:-}

The main aim of the study is to assess the extent of attitudinal change of the respondents with reference to their marriage (early or late) and family (type and size), in relation to their education. Further, mother's attitude towards dowry in daughter's marriage was also obtained. During interviews a significant change in the people's attitude (including girls \& parents) was observed in the rural area in Almora, and this could be noticeable throughout the whole interviewed sequence. The socio-educational profile of school going girl children indicates that a remarkable changing scenario is going through education and now the confident girl children in different age groups with different economical category are the product of different educational effort.

The attitude of parents in rural areas, towards the early marriage for girls has changed over the years and a greater proportion of them are in favour of late marriage for their daughters. The nature of the responses suggests as the educational level increases the girls in rural area are being increasingly consulted in the choice of their husbands; they are so confident about their decision and expressed that they will marry after 25 years after becoming economically independent. When the parents were asked about their daughter's marriage and at what age they want to marry their daughters, interestingly majority of the parents, particularly mothers, expressed their willingness to educate their daughter up to higher level and were not favour of early marriage. Such change in attitude can also be attributed to education of parents particularly that of mothers who play an influential role in educating their children at school, has been reported (Bernstein, 1997; Kumar, 2007; Panda, 2015). A recent study in rural area of Almora district has also demonstrated a positive role of mother's education level in their daughter's education (Nandi \& Joshi, 2015).

Srivastava (1974) noted that education had a positive role in promoting family planning in Kumaun region of Uttarakhand and has been an important determinant in deciding the marriage age. Hence the need for greater emphasis to female education was highlighted (Srivastava, 1982). Child marriage was reported prevalent in hills of Uttarakhand in early days particularly to support agricultural work which was the basis of income (Chandola, 1999). However, with changing time and gradual development of mindset of the people of higher castes (Brahmins and Rajputs), the system of child marriage subsequently decreased amongst them. But it still persisted amongst the lower caste and illiterate people (Chandola, 1999). The results of this investigation clearly reveals that girls prefer to get married only after first settling down, preferably after 25 years. It must be mentioned and at the same time supported by recent data of the last few decades that there has been considerable change in the mean age at marriage in the hill region of Uttarakhand. The mean age of marriage of female of Uttarakhand was reported to be 22.2 years (21.7 in Rural \& 23.3 in Urban) compared to 21.8 years (21.6 in Rural \& 25.8 in Urban) in Almora district (Annual Health Survey 2011-12. Fact sheet-Uttarakhand.http://www.censusindia.gov.in; retrieved on $10^{\text {th }}$ June, 2015). It must be indicated that the mean age at marriage for girls in the country is also 22.2 years (http://www.medindia.net/ health_statistics/general/ marriageage.asp; retrieved on 14th November, 2015). In this context it can be mentioned that the raising of age of consent of marriage is not likely to create problem in normal life of people when their social status is improved by providing the facilities for higher education and other useful engagements for girls in rural and urban areas as well which will may be also helpful from financial point of view (Baburam, 2005).

It is interesting to note that the parents of the respondents are now showing their opinion about dowry to their daughter's marriage. They opined that they favour dowry within their limits. They want to give dowry as a gift to their daughter because they think that dowry helps the new couple to have a convenient start in practical life. It is very surprising to learn that dowry is generally not demanded from groom's side on bride's family in rural areas of Almora. Mostly the parents give the useful items during their daughter's marriage as a gift. It is also found that some parents are not favour of dowry, according to them being economically independent after completing education is better than dowry. It can be noticed that the type of family appears to have influence on respondents' education, as more school going respondents lived in a nuclear family. However, some drop-out students were present in nuclear family and it reflected the requirement of these girls for domestic work. It is found that nuclear family system is now a modern trend.

The present study shows a gradual change occurring in the mind set of the parents who provide more care and opportunities to their children. Maximum respondents belonged to small family. According to their parents (mostly 
mothers), a small family helps in proper upbringing, providing better quality of education; moreover, a family bearing a large number of children adversely affects the health of the mother as well as that of the children. Further, satisfaction of the children's genuine physical and psychological needs, especially for parental love is more important for happiness of the children. But it is very difficult to provide proper care to the children in a large family. Therefore, the altered idea of small family happiness could be cherished by most of the respondents' parents.

The status of girl children in rural areas needs to be examined further. Moreover, several challenges would come their way but the girl children have to overcome them. In the present study it was found that the attitude of girls towards profession and their participation in different occupation are changing and showing more favourable attitude towards these changes. The findings reveal that girl children in rural Almora are inclined towards employment because they themselves and their parents realized that only through economic independence they can achieve economic freedom and empowerment.

Table 1:- Table depicting the geographical position, area, population, schools and literacy rate of different sites in Almora district selected for the study.

\begin{tabular}{|c|c|c|c|c|c|}
\hline \multirow[t]{2}{*}{ S.N. } & \multirow[t]{2}{*}{ Parameter } & \multicolumn{4}{|l|}{ Blocks } \\
\hline & & Hawalbagh & Tarikhet & Lamgarah & Dhaula Devi \\
\hline 1. & Geographical position* & $\begin{array}{l}29^{\circ} 38.567^{\prime} \mathrm{N} \\
79^{\circ} 37.968^{\prime} \mathrm{E}\end{array}$ & $\begin{array}{l}29^{\circ} 36.691^{\prime} \mathrm{N} \\
79^{\circ} 24.662^{\prime} \mathrm{E}\end{array}$ & $\begin{array}{l}29^{\circ} 26.786^{\prime} \mathrm{N} \\
79^{\circ} 33.581^{\prime} \mathrm{E}\end{array}$ & $\begin{array}{l}29^{\circ} 34.597^{\prime} \mathrm{N} \\
79^{\circ} 54.023^{\prime} \mathrm{E}\end{array}$ \\
\hline 2. & Altitude $(\mathrm{m})^{*}$ & 1213 & 1487 & 1460 & 1741 \\
\hline 3. & $\begin{array}{l}\text { Distance }(\mathrm{km}) \text { from Almora } \\
\text { town }\end{array}$ & 14 & 56 & 33 & 35 \\
\hline \multicolumn{6}{|c|}{ As per Census of India, $2011^{\#}$} \\
\hline 5. & Total population & 67447 & 66831 & 52169 & 60620 \\
\hline 6. & Male population & 32697 & 31479 & 25132 & 28291 \\
\hline 7. & Female population & 34750 & 35352 & 27037 & 32329 \\
\hline 9. & $\begin{array}{l}\text { Sex ratio } \\
\text { (females/1000 males) }\end{array}$ & 1062 & 1123 & 1075 & 1142 \\
\hline 10. & Literacy rate & 83.69 & 88.75 & 77.09 & 73.01 \\
\hline \multirow[t]{2}{*}{11.} & Male literacy rate & 94.49 & 95.03 & 91.39 & 87.66 \\
\hline & Female literacy rate & 73.69 & 74.03 & 64.09 & 60.67 \\
\hline 12. & Total area $(\mathrm{sq} \mathrm{km})$ & 201.8 & 243.2 & 214.2 & 324.4 \\
\hline 13. & No. of family & 14578 & 14406 & 10582 & 12732 \\
\hline
\end{tabular}

*Block HQs; Information gathered from Google Earth as on $16^{\text {th }}$ April, 2015.

\# Source: VikasBhawan, Almora, Govt. of Uttarakhand (based on Census of India, 2011).

Table 2:- Education and age of the respondents.

\begin{tabular}{|l|l|l|l|l|}
\hline \multirow{2}{*}{$\begin{array}{l}\text { Respondents' } \\
\text { education }\end{array}$} & Age & $\mathbf{1 1 - 1 5}$ yrs & Total \\
\cline { 2 - 5 } & $\mathbf{6 - 1 0}$ yrs & $4(3.96)$ & - & \\
\hline Below 5 & $54(96.43)$ & $90(89.11)$ & $12(8.39)$ & 102 \\
\hline Below 10 & - & - & $126(88.11)$ & 126 \\
\hline Below 12 & - & $7(6.93)$ & $5(3.50)$ & 14 \\
\hline Drop-out & $2(3.57)$ & $\mathbf{1 0 1}(\mathbf{3 3 . 6 7})$ & $\mathbf{1 4 3 ( 4 7 . 6 6 )}$ & $\mathbf{3 0 0}$ \\
\hline
\end{tabular}

Source: Based on Primary Field work; Values in parentheses are in percentage. 


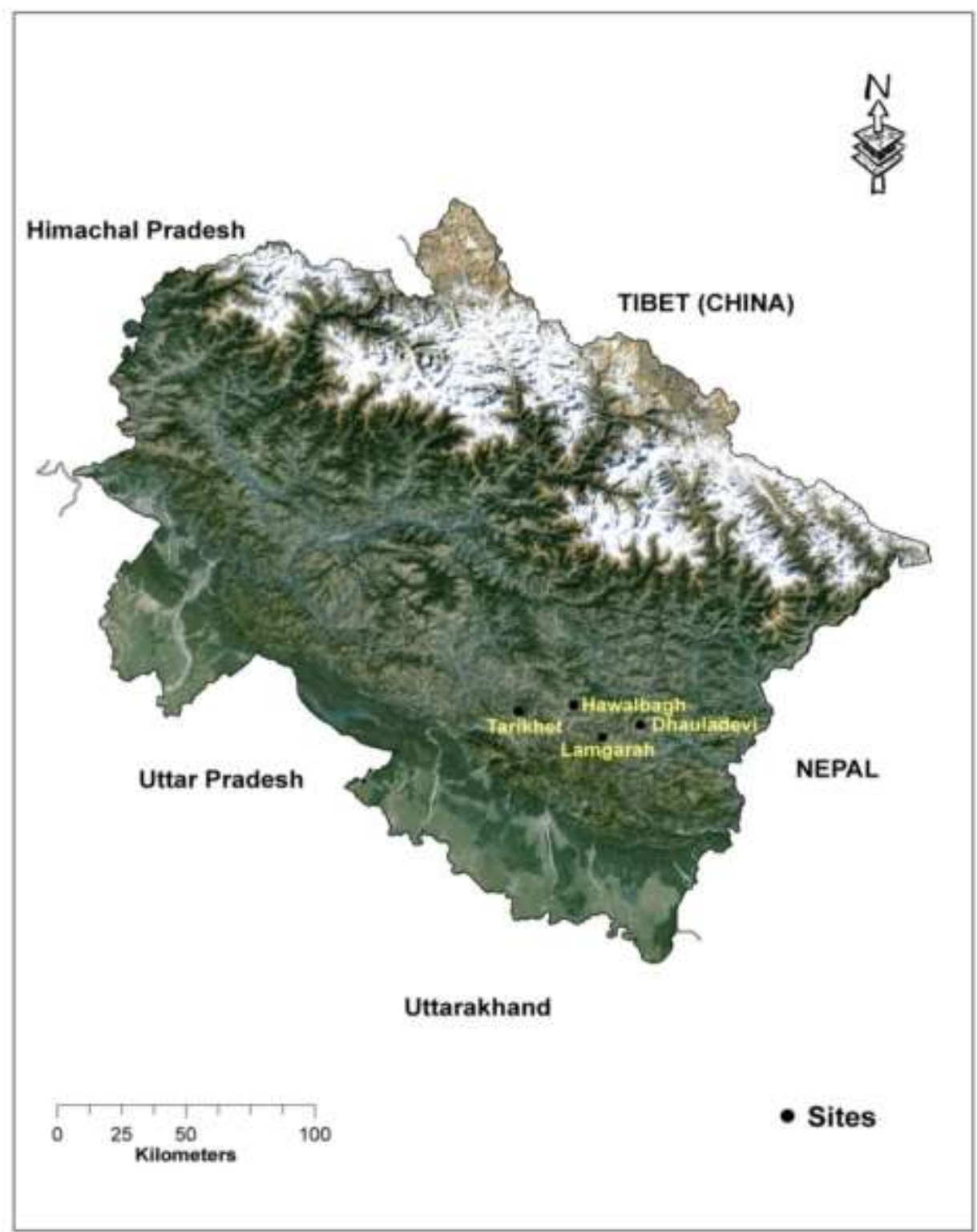

Figure 1:- Map of Uttarakhand showing the different study sites in Almora district (Source: Google Earth). 


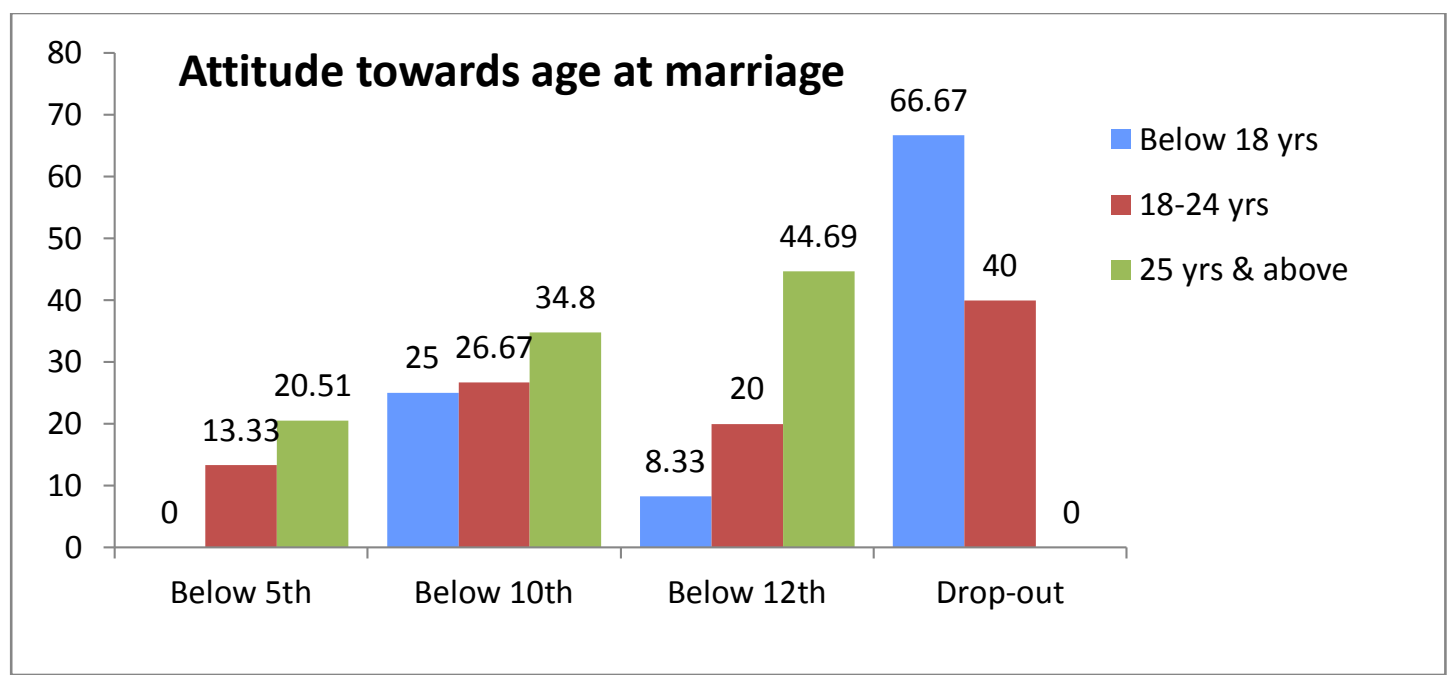

Figure 2:- Graph showing respondents' education and attitude towards age at marriage.

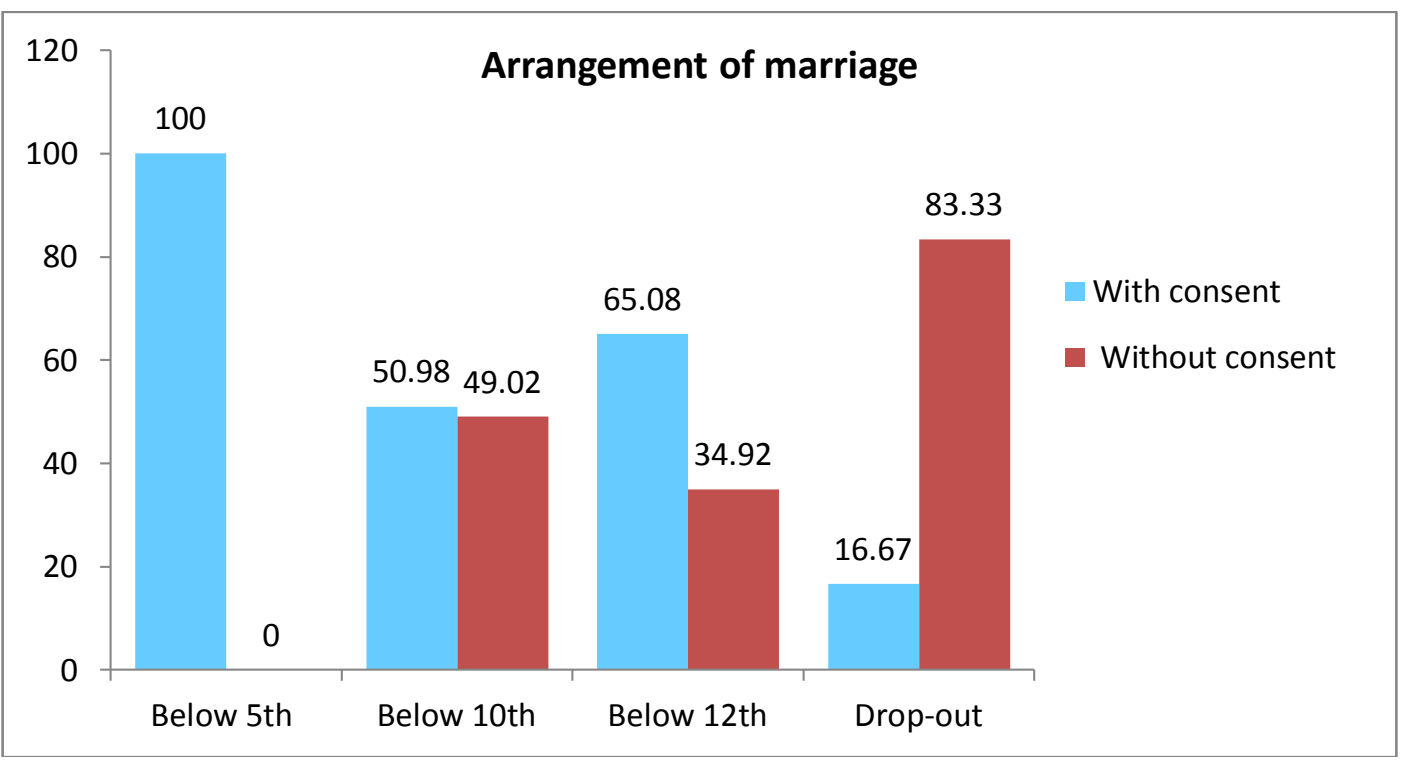

Figure 3:- Graph showing respondents' education and attitude towards arrangement of marriage. 


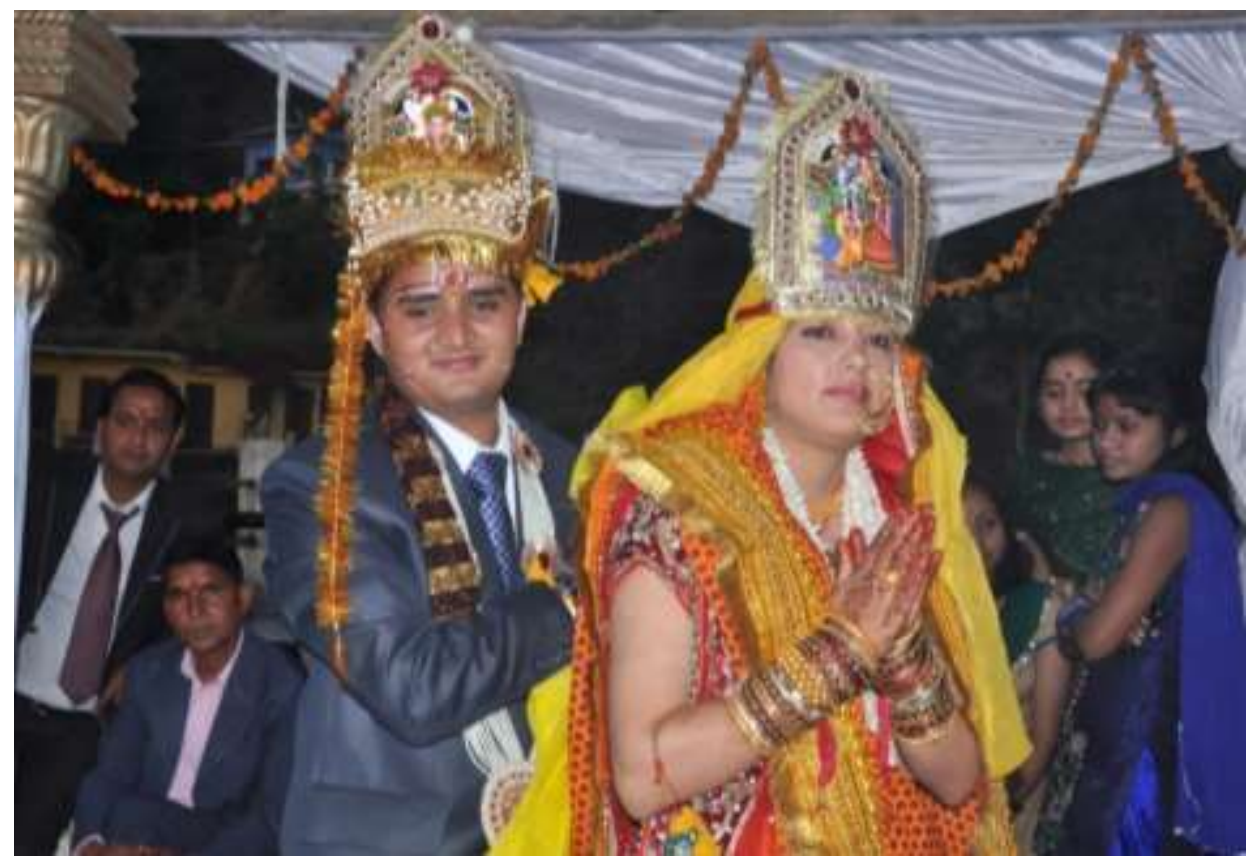

Figure 4:- A Kumauni couple performing the rituals during their marriage ceremony.

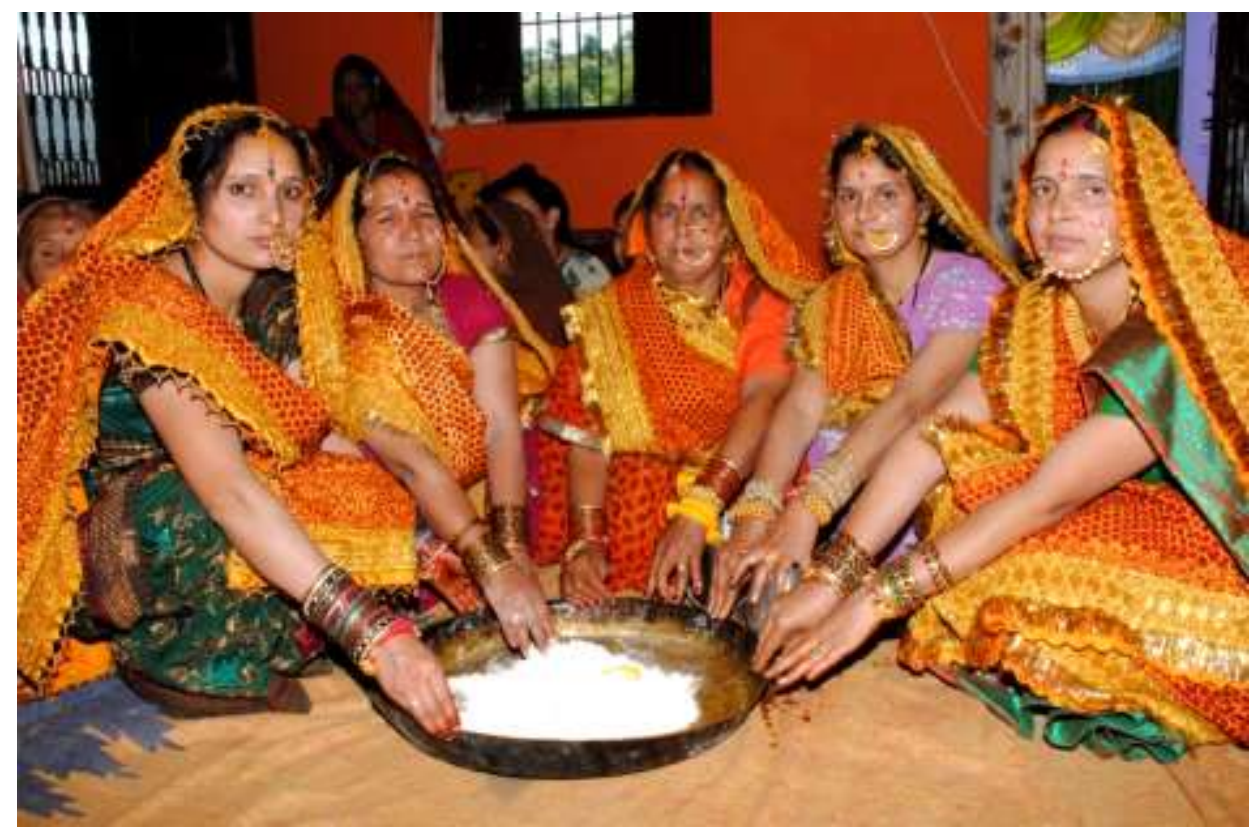

Figure 5:- Kumauni women in traditional attire performing marriage rituals. 


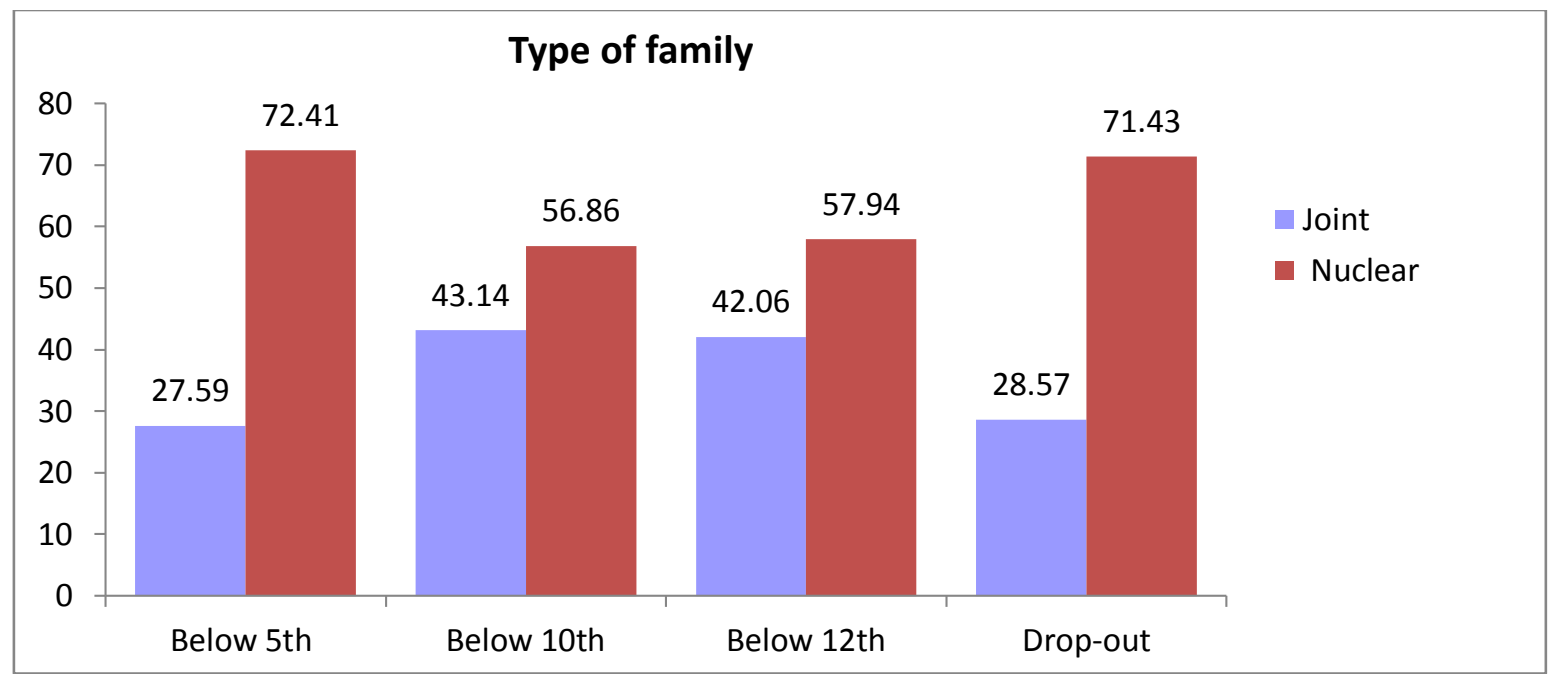

Figure 6:- Graph showing respondents' education and type of family.

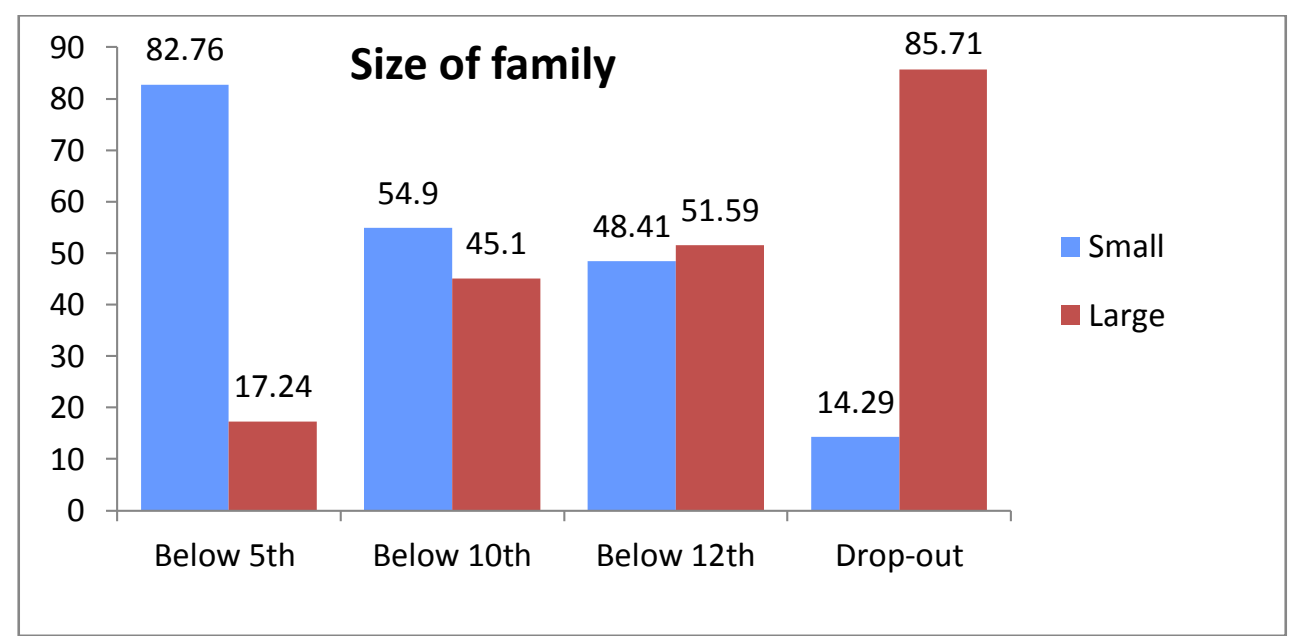

Figure 7:- Graph showing respondents' education and size of family.

\section{Acknowledgement:-}

The author is grateful to Dr. H.C. Joshi, Department of Economics, Kumaun University, SSJ Campus, Almora for initial guidance, and all anonymous school teachers and student respondents. The name of the respondents has been deliberately changed to hide their actual identity. The author is thankful to Dr Lalit Giri for permitting to use his marriage and family photographs.

\section{References:-}

1. Annual Health Survey (2011-12). Fact sheet- Uttarakhand. Office of the Registrar General \& Census Commissioner, New Delhi, India (http://www.censusindia.gov.in). Retrieved on $10^{\text {th }}$ June, 2015.

2. Anonymous (2005). Course material on Rural Social Development. MRDE-101, Block-1. School of Continuing Education; Indira Gandhi National Open University, New Delhi.

3. Baburam (2005). Raising the age of marriage, In: Usha Sharma (ed.), Marriage in Indian society: From tradition to modernity, Vol. 2, pp. 63-69. New Delhi: Mittal Publications.

4. Bernstein, B. (1997). Class and pedagogies: Visible and invisible, In: A.H. Halsey, H. Lander, P. Brown, A.S. Wells (eds), Education: Culture, economy and society, pp. 59-79. New York: Oxford University Press.

5. Bloom, D.E. \& Trussell, J. (1984). What are the determinants of delayed child bearing and permanent childlessness in the United States? Demography, 21: 591-611.

6. Caldwell, J. C. et al. (1983). The causes of marriage change in South India. Population Studies, 37: 343-361. 
7. Census of India (2011). Wikipedia; http://en.wikipedia.org/wiki/ 2011_census_of_India). Retrieved on $29^{\text {th }}$ April, 2014.

8. Chandola, Sarla (1999). Uttarakhand ka loksahitya aurjanjeevan (Hindi), 272 p. New Delhi: Takshila Prakashan, ISBN 81-85727-60-0.

9. Driver, Edwin (1963). Differential fertility in Central India, Princeton: Princeton University Press.

10. http://en.wikipedia.org/wiki/World_population- Wikipedia, the free encyclopedia. Retrieved on 29th April, 2014.

11. http://www.medindia.net/health_statistics/general/marriageage.asp. Retrieved on 14th November, 2015.

12. Hussain, I. Z. (1972). Educational status and differential fertility in India, In: I.Z. Hussain (ed.), Population analysis and Studies. Bombay: Somaiya Publications.

13. Jejeebhoy, S.J. (1995). Women's education, autonomy, and reproductive behaviour: Experience from developing countries. Oxford: Clarendon Press.

14. Jha, S. S. et al. (1969). Family planning attitudes and practices in women: A study in two groups. The Journal of Family Welfare, 16 (1): 10-24.

15. Joshi, S.C. (1988). State of education and literacy in Kumaun, In: K.S. Valdiya (ed.), Kumaun- Land and People, pp. 341-345. Nainital: Gyanodaya Prakashan.

16. Kammeyer, K.C.W. \& Ginn, H. Z. (1988). An introduction to population. New Delhi: Archives Books Ltd.

17. Kapadia, K. (1966). Marriage and family in India. Bombay: Oxford University Press.

18. Kaufman, G.L. \& Meekers, D. (1998). The impact of women's socioeconomic position on marriage patterns in subSaharan Africa. Journal of Comparative Family Studies, 29 (1): 101-114.

19. Kaur, Ramandeep (2013). Low female literacy rate and its impact on our society (http://www.mapsofindia.com/myindia/society/low-female-literacy). Retrieved on $17^{\text {th }}$ October, 2013.

20. Krishnamurthy, K.G. (1968). Research in family planning in India. Delhi: Sterling Publishers.

21. Kumar, Nita (2007). The politics of gender, community and modernity: Essays on education in India. Oxford University Press, New Delhi.

22. Majumdar, K. (2001). Dowry related violence: An over view. Indian Journal of Social Work, 3(62): $397-413$.

23. Mandelbaum, D. (1999). Dowry deaths in India. Commonweal,8: 18-20.

24. Nandi, Shibani \& Joshi, H.C. (2015). Status of girl's education in selected rural areas of Almora district in Uttarakhand. International Journal of Applied Research, 1 (12): 237-243.

25. Oppenheimer, V. K. (1988). A theory of marriage timing. American Journal of Sociology, 94: 563-591.

26. Panda, Gayatri (2015). Maternal involvement in everyday schooling: a micro study. Indian Journal of Gender Studies, 22 (2): 219-242.

27. Pande, G.C. (1988). Role and status of women in Kumaun, In: K.S. Valdiya (ed.), Kumaun- Land and People, pp. 161-177. Nainital: Gyanodaya Prakashan.

28. Raina, E.L. (1972). Fertility status of Indian women. In: Family planning status of women in India, pp. 88-101. New Delhi: Central Institute of Research and Training in Public Cooperation.

29. Rajaraman, Indira (1983). Economics of bride price and dowry. Economic and Political Weekly, 18(8): $275-279$.

30. Rindfuss, R.R. \& St. John, C. (1983). Social determinants of age at first birth. Journal of Marriage and the Family, 45: 553-565.

31. Roulet, Marguerite. (1996). Dowry and prestige in North India. Contributions to Indian Sociology (New Series), 30 (1): 89-106.

32. Saxena, D.N. (1975). Report of family planning and fertility survey of Kumaun region. Series 8, Survey report V, Lucknow: Demographic Research Centre.

33. Sen, Amartya (1997). Editorial: Human capital and human capability. World Development, 25(12): 1959-1961.

34. Srinivas, M.N. (1983). Some reflections on dowry. New Delhi: Oxford University Press.

35. Srivastava, Gouri (2005). Women education in India- Issues and dimensions. Delhi: Academic Excellence.

36. Srivastava, J.N. (1974). A study of inter-district variations in family planning acceptance in Kumaun hills. Series-C, pp. 70-73. Lucknow: Demographic Research Centre, Lucknow University.

37. Srivastava, J.N. (1982). Determinants of age at marriage. Series- C, Analytical Report, pp. 60-64. Lucknow: Demographic Research Centre, Lucknow University.

38. Srivastava, J.N. 1979. Incidence of child marriage, widowhood and divorce among female. Series-C, U.P. Occasional Paper-21, pp. 12-17. Lucknow: Population Research Centre.

39. Tewari, S.G. (1987). The requisites of efficient area planning in drought-prone areas of U.P. hills. Presidential Address, Proceedings of Seminar on Drought Prone Areas, pp. 3-4. Nainital: Administrative Training Institute.

40. Tripathi, Beena (1980). Fertility pattern in Kumaun. Ph.D. Thesis, 365 p. Kumaun University, Nainital, India.

41. United Nations (1987). Fertility behaviour in the context of development: Evidence from the World Fertility Survey. Washington DC: World Bank.

42. United Nations (1988). First marriage: Patterns and Determinants. Washington DC: World Bank. 